\title{
LACK OF CORRESPONDENCE BETWEEN GENETIC AND MORPHOLOGIC VARIABILITY PATTERNS IN ATLANTIC HERRING (CLUPEA HARENGUS)
}

\author{
NILS RYMAN,* ULF LAGERCRANTZ,* LEIF ANDERSSON,* \\ RANAJIT CHAKRABORTY, $\dagger$ AND RUTGER ROSENBERG $\ddagger$ \\ * Department of Genetics, University of Stockholm, S-106 91 Stockholm, Sweden; † Center \\ for Demographic and Population Genetics, Health Science Center at Houston, The University \\ of Texas, PO Box 20334, Houston, Texas 77025, USA; $\ddagger$ Institute of Marine Research S-453 00 \\ Lysekil, Sweden
}

Received 15.v.84

\section{SUMMARY}

The Atlantic herring (Clupea harengus) stock complex is confusing from the perspectives of both evolutionary biology and systematics. There are numerous ecologically and morphologically divergent stocks classified as species, subspecies, races, tribes, etc. with an unknown degree of genetic differentiation and reproductive isolation between them. The genetic population structure of herring from the Scandinavian waters was analysed electrophoretically. The pattern for distribution of genetic variation was compared to that of the morphological characters most frequently used for stock classification, i.e., the number of vertebrae and keeled scales.

Fish were collected from 17 locations distributed from the northern Gulf of Bothnia to the north-east Atlantic off the west coast of Norway. The genetic analysis was based on 17 electrophoretic loci, 13 of which were variable. There are statistically significant allele frequency heterogeneities, but there is a conspicuously small amount of genetic differentiation, even between stocks classified as representing different subspecies. More than 99 per cent of the total gene diversity was found within populations, and genetic distances are typically of the order of 0.001 . The genotypic distribution of the total material is very similar to the one expected if all the samples had been drawn from a single panmictic population. There appears to be no association between the variation of morphological characters and that at electrophoretic loci, and this is true for the variation between as well as within samples. Data suggest that stocks either diverged rather recently or that the amount of gene flow between groups of fish classified as stocks has been large enough to prevent substantial differentiation, and that morphologic and ecologic divergence may to a large extent be environmentally induced.

\section{INTRODUCTION}

The genetic structure of the Atlantic herring (Clupea harengus) stock complex represents a so far unsolved problem of great significance from the perspectives of both evolutionary biology and fisheries management. Dozens of ecologically and morphologically more or less divergent stocks, frequently classified as, e.g., species, subspecies, races, tribes, groups, etc., have been recognised on both sides of the north Atlantic (Heincke, 1898; Bückman and Parrish, 1958; Parrish and Saville, 1965; Iles and Sinclair, 1982; Rosenberg and Palmén, 1982; and references therein). It is difficult to comprehend the biological reason for this multiplicity of stocks. As pointed out by Iles

§ Present address: Department of Animal Breeding and Genetics, Swedish University of Agricultural Sciences, S-750 07 Uppsala, Sweden. 
and Sinclair (1982) the richness of stocks cannot be explained by the latitudinal range of herring distribution alone; as an example, they compared with the range of mackerel which is as great as that of herring, but far fewer stocks of mackerel are recognised. Identification and characterisation of herring stocks is usually based on place and time for spawning and meristic characters, e.g., the number of vertebrae, keeled scales, fin rays, gillrakers, and also otolith type, and the stocks usually differ considerably in one or more of these characteristics (e.g., Parrish and Saville, 1965; Rosenberg and Palmén, 1982). The genetic basis for the variation of these characters is complex, and they are also under the influence of numerous environmental factors (Blaxter, 1958; Hempel and Blaxter, 1961 ; Parrish and Saville, 1965). As a matter of fact, the degree of reproductive isolation and the amount of genetic divergence among stocks is essentially unknown, and the genetic basis of the Atlantic herring stock concept is still to be resolved.

There are only few electrophoretic studies on Atlantic herring analysing the variation of characters with an inferred true genetic basis for the variability pattern; they are all based on a rather small number of electrophoretic loci or samples (locations, stocks etc.). The results point at genetic homogeneity over large geographic areas and a very small amount of genetic divergence in those cases where genetic heterogeneity was indicated at all (Andersson et al., 1981; Grant, 1981; Kornfield et al., 1982a). Those findings are surprising considering the large number of stocks that have been identified and the behavioural, ecological, and morphological differences that have been observed among them. The purpose of the present investigation is to compare the differentiation pattern at electrophoretic loci with that of meristic characters used for identification and classification of different stocks. We present the results of a study of several Atlantic herring stocks from all over the Scandinavian waters examining the joint distribution of morphological and electrophoretically detectable variation. Our study represents the most extensive one on electrophoretic variation in Atlantic herring that we are aware of and the only one on this species that attempts to relate the levels of genetic and morphological divergence.

\section{MATERIALS AND METHODS}

The analysis is based on a total of 1415 fish collected from 17 locations around Scandinavia (fig. 1 and table 1). Three of the samples included in the present analysis $(E, J$, and $M$ ) are identical to those presented by Andersson et al. (1981). Stock classification was based on location, gonadal development in relation to time of collection, the number of vertebrae (VS) and keeled scales $\left(K_{2}\right)$; in a few cases otolith type, otolith length, and fish length frequency distribution were also considered (Parrish and Saville, 1965; Ackefors, 1977a, 1977b; Aneer, 1979; Petursson and Rosenberg, 1982; Rosenberg and Palmén, 1982). For technical reasons the number of vertebrae and keeled scales were not recorded in samples $A, D, P$ and $Q$.

Electrophoretic techniques, staining procedures, genetic interpretation of zymogram patterns, and locus designations have been described previously (Andersson et al., 1981). Also, the results of formal genetic studies indicating a simple Medelian inheritance of codominant autosomal alleles at loci coding for GPI, IDH, LDH, ME and PGM have recently been published by Kornfield et al. (1981). 


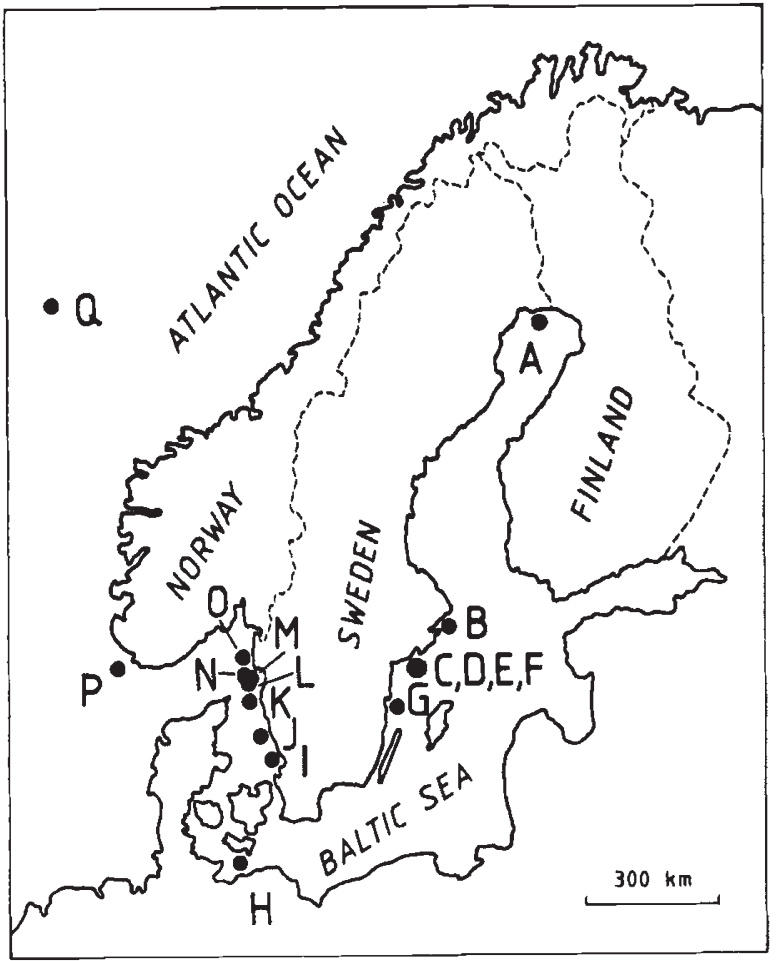

FIG. 1. Geographic location of sampling sites (cf. table 1).

The prime purpose of the present study is to analyse the genetic population structure and not to estimate electrophoretic heterozygosity from randomly selected loci (see Andersson et al. (1981) and Grant (1981) for such estimates). The loci chosen for analysis are essentially those which had been variable in our previous study (Andersson et al., 1981) and a few additional ones which could be easily read on the buffer-tissue combinations selected for the variable ones. The following 17 loci were scored (enzyme and EC nomenclature in parentheses): $A A T-2$ (aspartate aminotransferase, EC 2.6.1.1), EST-4 (esterase), GAPDH-1 (glyceraldehyde-phosphate dehydrogenase, EC 1.2.1.12), GPD-1 (glycerol-3-phosphate dehydrogenase, EC 1.1.1.8), G-6-PDH (glucose-6-phosphate dehydrogenase, EC 1.1.1.49), GPI (glucosephosphate isomerase, EC 5.3.1.9), IDH-1 and 2 (isocitrate dehydrogenase, EC 1.1.1.42), $L D H-1$ and 2 (lactate dehydrogenase, EC 1.1.1.27), $M D H-3$ and 4 (malate dehydrogenase, EC 1.1.1.37), $M E-1$ and 2 (malic enzyme, EC 1.1.1.40), PGDH (phosphogluconate dehydrogenase, EC 1.1.1.44), $P G M-1$ (phosphoglucomutase, EC 2.7.5.1), and $S O D$ (superoxide dismutase, EC 1.15.1.1).

Probably due to storage effects EST -4 could not be reliably scored in all samples; that locus was therefore excluded from some of the statistical analyses. There was variation (more than one allele) at all loci except for $G A P D H-1, G-6-P D H$. In contrast to our previous preliminary study (Andersson et al., 1981) $M D H-3$ and $M E-1$ exhibited variation in the course of the present investigation, and new alleles were also observed at all the 
TABLE 1

Atlantic herring (Clupea harengus) sampling information and sample classification (cf. fig. I). A.S. =autumn spawners and S.S. = spring spawners. For samples which were not in spawning condition the classification as spring or autumn spawners was inferred from the stage og gonadal development

\begin{tabular}{|c|c|c|c|c|c|c|}
\hline \multirow{2}{*}{\multicolumn{2}{|c|}{$\begin{array}{l}\text { Collection site } \\
\text { and } \\
\text { code }(A-Q)\end{array}$}} & \multirow[b]{2}{*}{ Area } & \multicolumn{2}{|c|}{ Location } & \multirow[b]{2}{*}{ Date } & \multirow[b]{2}{*}{ Classification } \\
\hline & & & $\mathbf{N}$ & E & & \\
\hline A & Kalix & Gulf of Bothnia & $65^{\circ} 52^{\prime}$ & $22^{\circ} 43^{\prime}$ & 800626 & Baltic herring (C.h. var. membras); \\
\hline B & Vaxholm & Baltic Sea & $59^{\circ} 26^{\prime}$ & $18^{\circ} 18^{\prime}$ & 790827 & $\begin{array}{l}\text { Baltic herring (C.h. var. membras); } \\
\text { S.S. }\end{array}$ \\
\hline C & Himmerfjärden & Baltic Sea & $59^{\circ} 04^{\prime}$ & $17^{\circ} 45^{\prime}$ & 790705 & $\begin{array}{l}\text { Baltic herring (C.h. var. membras); } \\
\text { S.S. }\end{array}$ \\
\hline D & Himmerfjärden & Baltic Sea & $59^{\circ} 04^{\prime}$ & $17^{\circ} 45^{\prime}$ & 791217 & $\begin{array}{l}\text { Baltic herring (C.h. var. membras); } \\
\text { S.S. }\end{array}$ \\
\hline E & Käftudden & Baltic Sea & $58^{\circ} 55^{\prime}$ & $17^{\circ} 32^{\prime}$ & 781114 & $\begin{array}{l}\text { Baltic herring (C.h. var. membras); } \\
\text { S.S. }\end{array}$ \\
\hline$F$ & Askö & Baltic Sea & $58^{\circ} 49^{\prime}$ & $17^{\circ} 36^{\prime}$ & 790823 & $\begin{array}{l}\text { Baltic herring (C.h. var. membras); } \\
\text { S.S. }\end{array}$ \\
\hline G & Gamleby & Baltic Sea & $57^{\circ} 50^{\prime}$ & $16^{\circ} 27^{\prime}$ & 790820 & $\begin{array}{l}\text { Baltic herring (C.h. var. membras); } \\
\text { S.S. }\end{array}$ \\
\hline H & Fehmarn & Baltic Sea & $54^{\circ} 50^{\prime}$ & $11^{\circ} 30^{\prime}$ & 790923 & $\begin{array}{l}\text { Baltic herring (C.h. var. membras); } \\
\text { A.S. (Spawning condition) }\end{array}$ \\
\hline 1 & Båstad & Kattegat & $56^{\circ} 26^{\prime}$ & $12^{\circ} 52^{\prime}$ & 790529 & $\begin{array}{l}\text { Mixed sample (Kattegat S.S. and } \\
\text { others) }\end{array}$ \\
\hline J & Träslövsläge & Kattegat & $57^{\circ} 03^{\prime}$ & $12^{\circ} 11^{\prime}$ & 781023 & $\begin{array}{l}\text { Kattegat S.S. (possible minor contri- } \\
\text { bution of North Sea A.S.) }\end{array}$ \\
\hline $\mathbf{K}$ & Pölsan & Kattegat & $57^{\circ} 47^{\prime}$ & $11^{\circ} 30^{\prime}$ & 790404 & $\begin{array}{l}\text { Mixed sample (Kattegat and Skager- } \\
\text { rak S.S.) }\end{array}$ \\
\hline $\mathrm{L}$ & Måseskär & & $58^{\circ} 06^{\prime}$ & $11^{\circ}$ & & Skagerrak S.S. (Spawning condition) \\
\hline M & Gäven & Sk & $58^{\circ} 17^{\prime}$ & $11^{\circ}$ & 781023 & $\begin{array}{l}\text { Kattegat S.S. (possible minor contri- } \\
\text { bution of North Sea A.S.) }\end{array}$ \\
\hline $\mathbf{N}$ & Flatb & & $58^{\circ} 20^{\prime}$ & $11^{\circ}$ & & Skagerrak S.S. (Spawning condition) \\
\hline 0 & Hamburgsund & Skagerrak & $58^{\circ} 30^{\prime}$ & $11^{\circ} 13^{\prime}$ & 790319 & Skagerrak S.S. (Spawning condition) \\
\hline $\boldsymbol{\Gamma}$ & North Sea & North Sea & $58^{\circ} 06^{\prime}$ & $06^{\circ}$ & 790805 & North Sea A.S. \\
\hline Q & Atlantic Ocean & Atlantic Ocean & $64^{\circ} 52^{\prime}$ & $10^{\circ} 15^{\prime}$ & 800207 & $\begin{array}{l}\text { North-east Atlantic oceanic group; } \\
\text { winter-spring spawners }\end{array}$ \\
\hline
\end{tabular}

other polymorphic loci except for $A A T-2, E S T-4$ and $M D H-4$. A single variant allele only was found at each of $I D H-1$ and $P G D H$.

Genetic distances and identities refer to those of Nei (1975). Gene diversity analyses were conducted following the logic of Nei $(1973,1975)$. Within each particular population (subunit) the gene diversity at a single locus is defined as

$$
h=1-\sum x_{i}^{2}
$$

where $x_{i}$ denotes the frequency of the $i$ th allele. The average gene diversity within populations $\left(H_{S}\right)$ is the average of $h$ over all loci and populations. The total gene diversity over all populations examined $\left(H_{T}\right)$ is defined in an analogous way on the basis of the unweighted mean allele frequencies (averaged over all populations). The total gene diversity is thus decomposed into two components

$$
H_{T}=H_{S}+D_{S T}
$$


representing the average gene diversity within populations $\left(H_{S}\right)$ and the gene diversity due to differences among populations $\left(D_{S T}\right)$. The $D_{S T}$ component may be further decomposed into components like

$$
H_{T}=H_{S}+D_{S i}+D_{i j}+\cdots+D_{k T}
$$

where the different $D_{i j}$ terms correspond to different levels in a hierarchical population structure. The relative importance of the various components are expressed in terms of $G$-values so that

$$
G_{i j}=D_{i j} / H_{T}
$$

denotes the relative contribution to the total gene diversity arising from differences between population groups on the $i j$ th level in the hierarchy. The computations of the gene diversity statistics were performed following the algorithms presented by Chakraborty (1980) and Chakraborty et al. (1982).

\section{Results}

\section{(i) Allele frequency distributions}

Allele frequencies at variable loci are given in table 2. Most of the variable loci are only weakly polymorphic, and not even the 99 per cent criterion for polymorphism is met for the major part of locus-location combinations. The $G$-statistic (Sokal and Rohlf, 1981) for allele frequency homogeneity is significant for four of the 13 loci (table 2) as is the sum of $G$-values for all loci $(G=261 \cdot 5 ; \mathrm{df}=202$ with $P<0.01)$. However, in spite of the statistical significance the most striking observation refers to the apparent similarity of allele frequencies among samples from taxonomically different groups collected over large geographic areas. Considering the fairly large samples sizes, the statistical significance observed at particular loci actually appears rather weak $(0.05>P>0.01$ in all cases). Genetic distances, summarised in the form of a dendrogram (fig. 2), are very small and far below the values usually observed between local populations of the same species ( $\mathrm{Nei}, 1975$ ). It should also be stressed that our present genetic distance values are calculated from a non-random sample of loci, i.e., the majority of loci have previously been proven variable, and such a selection usually inflates the estimates of genetic distance among conspecific populations. The dendrogram does not reveal any obvious pattern corresponding to, e.g., stock classification, spawning period, or geographic proximity. For instance, the $F$ and $P$ samples representing spring spawning Baltic herring and autumn spawning North Sea herring, respectively, cluster closely, as do the $\mathrm{H}$ and $\mathrm{A}$ samples from geographically very distant locations. Actually, the samples are so genetically similar that it is dubious what information can be inferred from a dendrogram (Felsenstein, 1982). The present dendrogram topology is very sensitive to removal of single samples or loci. Moreover, the spurious genetic distance (Nei, 1978) for the present set of samples is 0.0004 , a value that is close to the mid-point of the genetic distance scale used for the dendrogram. It should also be noted that this is the approximate branching point between the duplicate samples from the Himmerfjärden collection site (samples C and D). Altogether, these observations indicate a general lack of genetically relevant groupings among our samples. 


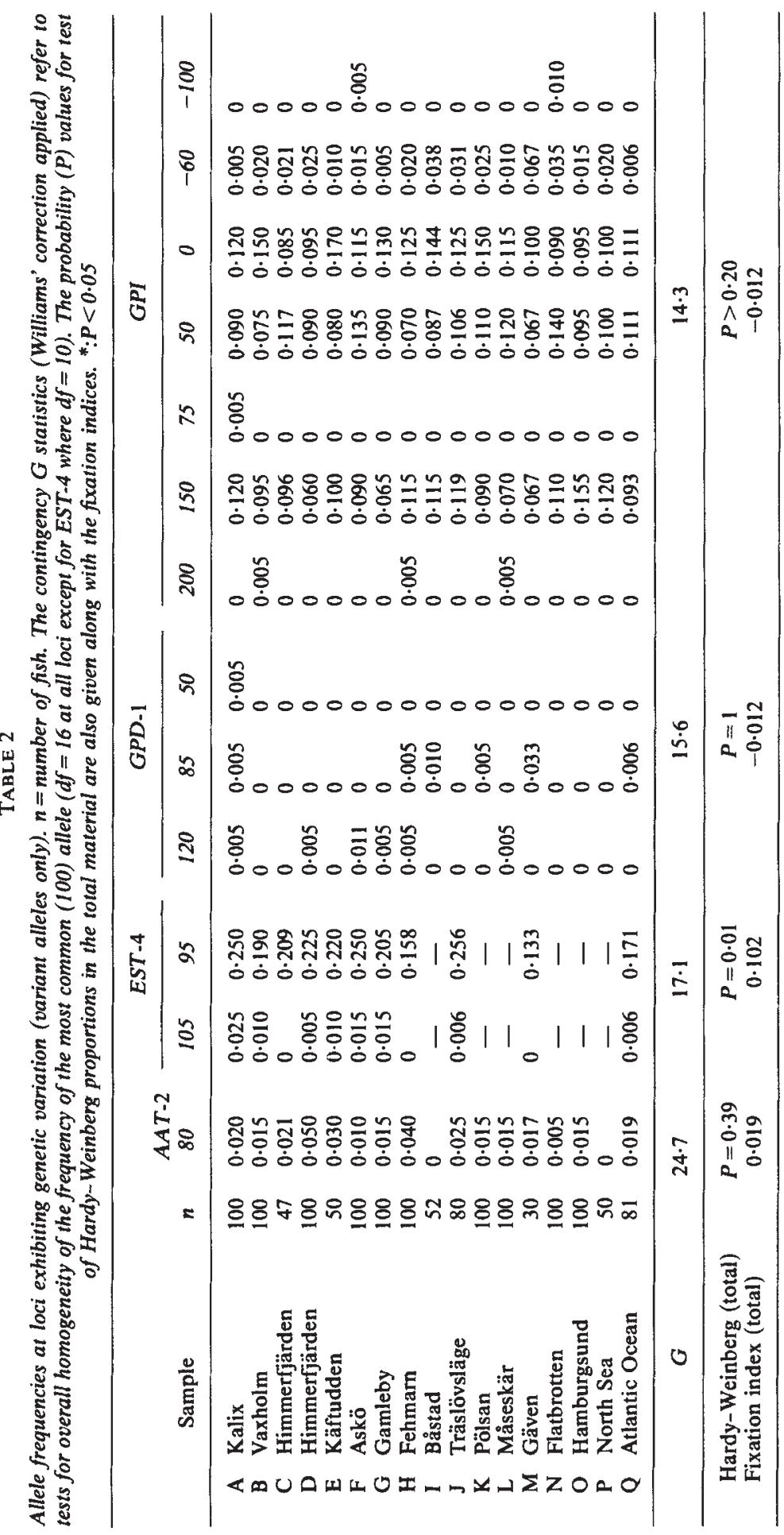




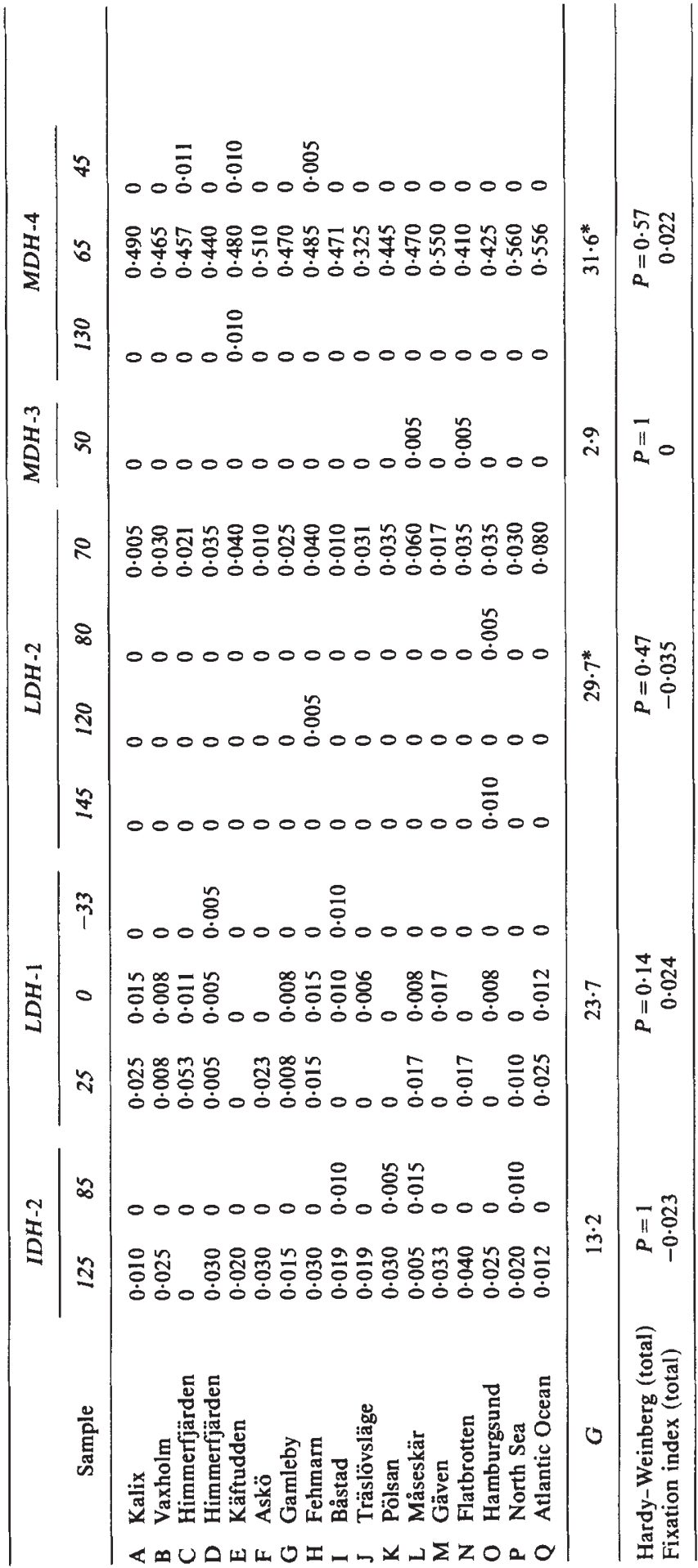




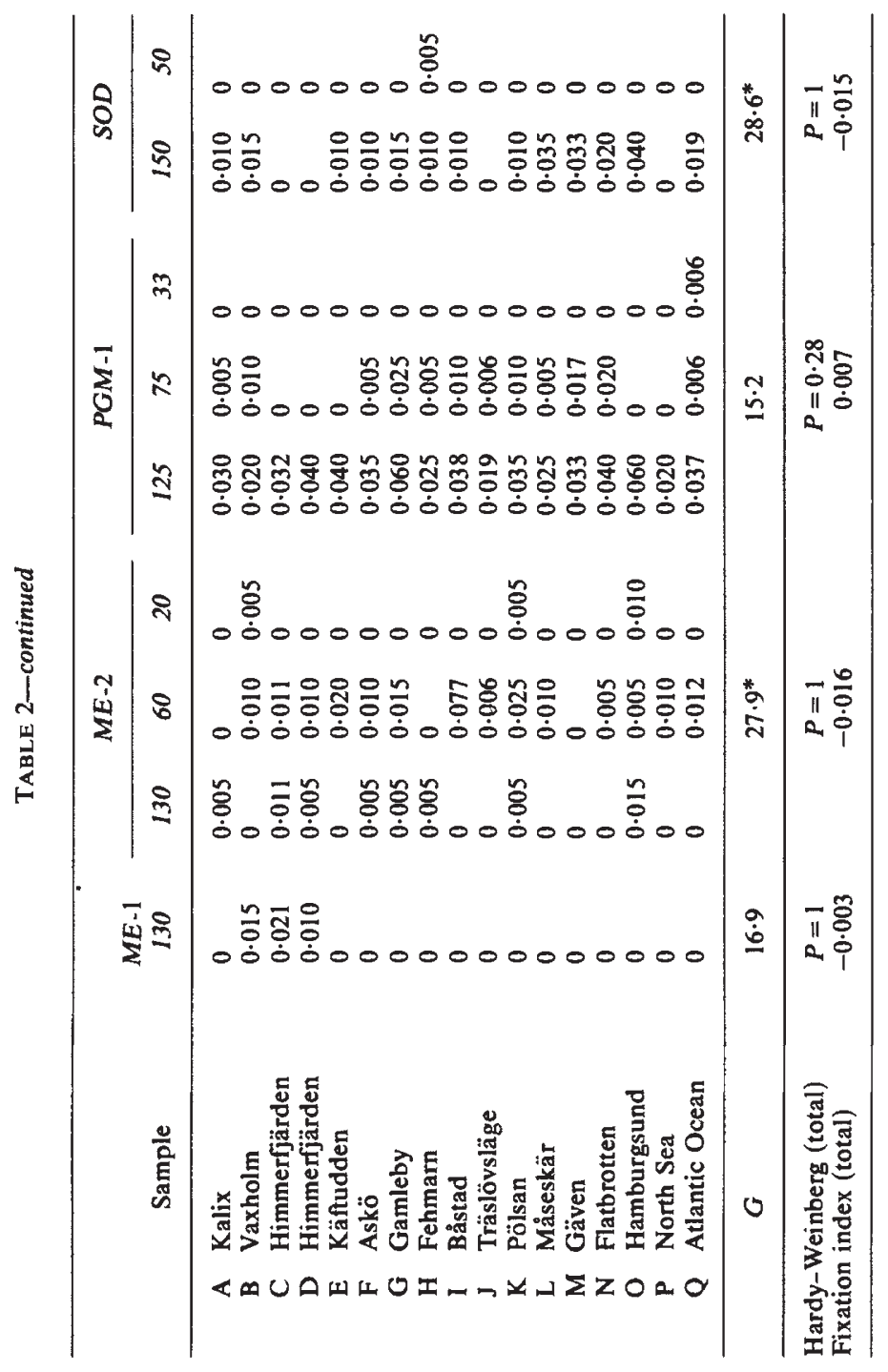




\section{GENETIC DISTANCE}

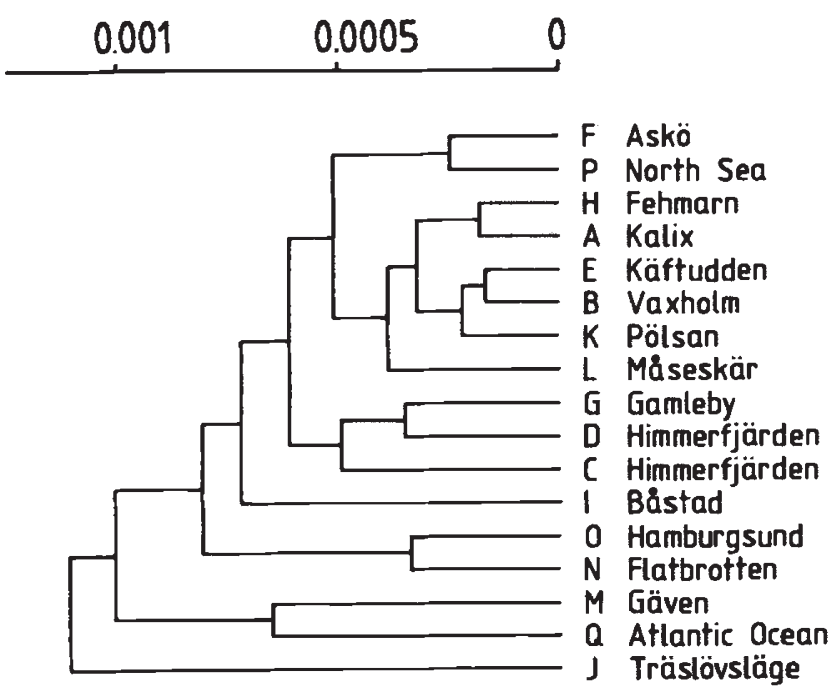

FIG. 2. Dendrogram (UPGMA; Sneath and Sokal, 1973) constructed from pairwise genetic distances (16 loci, EST -4 excluded) among all the 17 samples.

Variant alleles segregate at a low frequency at the majority of loci, and differences in the frequency of rare alleles contribute little to Nei's measure of genetic distance. In order to further inspect the data for the possible existence of an unrevealed genetic structuring we applied the qualitative method of Slatkin (1981), which is based on the distribution of average allele frequencies conditional on the number of populations (samples) each allele appears in. However, as expected from a visual inspection of table 2 the application of Slatkin's algorithm revealed no further indications of genetic heterogeneity.

Averaged over all the 17 samples (EST-4 excluded) more than 99 per cent of the total gene diversity was found within populations $\left(G_{S T}=0.009\right)$. Exactly the same estimate was obtained for the eleven samples where EST-4 was also scored and when including all loci in the analysis. Altogether, these observations indicate a very low amount of electrophoretically detectable allelic divergence.

\section{(ii) Genotypic distributions}

The fit of genotypic distributions to Hardy-Weinberg expectations was tested by the exact method of Vithayasai (1973). For loci with more than two alleles we applied an extended version of this test. Given the observed counts of the different alleles we calculated the exact hypergeometric probability of obtaining the observed genotypic distribution. More extreme cases were defined as those with lower probabilities than that of the case observed, and the total probability used for accepting or rejecting the null hypothesis was obtained by summing the probabilities of all cases being equally or 
more extreme than the one observed. Only rarely was it necessary to lump alleles to avoid unreasonably time-consuming computer operations. Of 170 tests performed within samples there was only one significant $(P<0.05)$ deviation from Hardy-Weinberg expectations (deficiency of EST-4 heterozygotes in the $\mathrm{D}$-sample with $P=0.015$ ). It should be noted that the conspicuously low frequency of significances is to a large extent explained by the very skewed allele frequencies at many loci resulting in an extremely low statistical power of any test (Emigh, 1980). When testing the total material for fit to Hardy-Weinberg expectations only one significant deviation was obtained, namely, a deficiency of heterozygotes at EST-4 (table 2 ). The point estimates of fixation indices ( 1 - [observed number of heterozygotes/expected number of heterozygotes]) are positive and negative in approximately half of the cases each (table 2), and there is no tendency towards a general lack of heterozygotes as would have been expected in a subdivided and genetically differentiated population (Wahlund effect).

In line with the above findings, there is no tendency towards a general gametic phase disequilibrium as is expected in subdivided populations ( $\mathrm{Nei}$ and $\mathrm{Li}, 1973$ ). When testing for deviations from gametic phase equilibrium (Hill, 1974), variant alleles were lumped and all loci treated as if segregating for two alleles only. Only four of the 66 possible pairwise tests on the total material ( $M D H-3$ excluded) are significant, and all of them on the 5 per cent level only $(0.05>P>0.01)$.

A third test for random association of alleles that allows for the joint variation at all polymorphic loci simultaneously can be performed on the distribution of individuals heterozygous at $0,1,2, \ldots$ etc. loci, respectively (Chakraborty, 1981). There is an almost perfect fit between the observed distribution and that expected from the heterozygosities at single loci within the different samples as well as in the total material $\left(\chi^{2}=1.43 ; \mathrm{df}=4\right.$ with $P>0 \cdot 80$ ). Furthermore, contingency chi square tests revealed no differences between locations with respect to the distribution of the number of heterozygous loci per individual $\left(\chi^{2}=55 \cdot 2 ; \mathrm{df}=48\right.$ with $\left.P>0 \cdot 20\right)$. Altogether these results indicate that the genotypic distribution observed in the combined total material resembles the one expected had all the samples been drawn from a single panmictic population. This finding is consistent with the absolutely very small, though in some cases statistically significant, allele frequency differences observed.

\section{(iii) Morphologic variation}

The number of vetebrae and keeled scales are the characters most frequently used for classification of herring stocks in the north-east Atlantic (e.g., Parrish and Saville, 1965; Rosenberg and Palmén, 1982), and there were highly significant heterogeneities among locations for both the means and variances of these characters (table 3 ). The major part of the between location variability of the number of vertebrae and keeled scales refers to differences between the spring spawning Baltic herring and that of the other locations (table 3), and the samples from the central Baltic constitute a distinct cluster in the dendrogram constructed from morphological distances (fig. 3). The distribution of morphologic variation between and within geographic areas is approximately the same for the number of vertebrae and kecied scales. The three geographic areas were somewhat arbitrarily 
TABLE 3

Average heterozygosity $(H)$ and mean $(\bar{x})$ and variance $\left(s^{2}\right)$ of the number of vertebrae (VS) and keeled scales $\left(K_{2}\right) . n=$ number of fish. $H$ is based on the 16 loci that could be reliably scored in all samples (excluding EST-4; all the $H$-estimates have standard errors of 0.04 or larger). The $F$ and $\chi^{2}$ values refer to tests for homogeneity of means and variances, respectively ${ }^{*}: P<0.05,{ }^{* * *}: P<0.001$

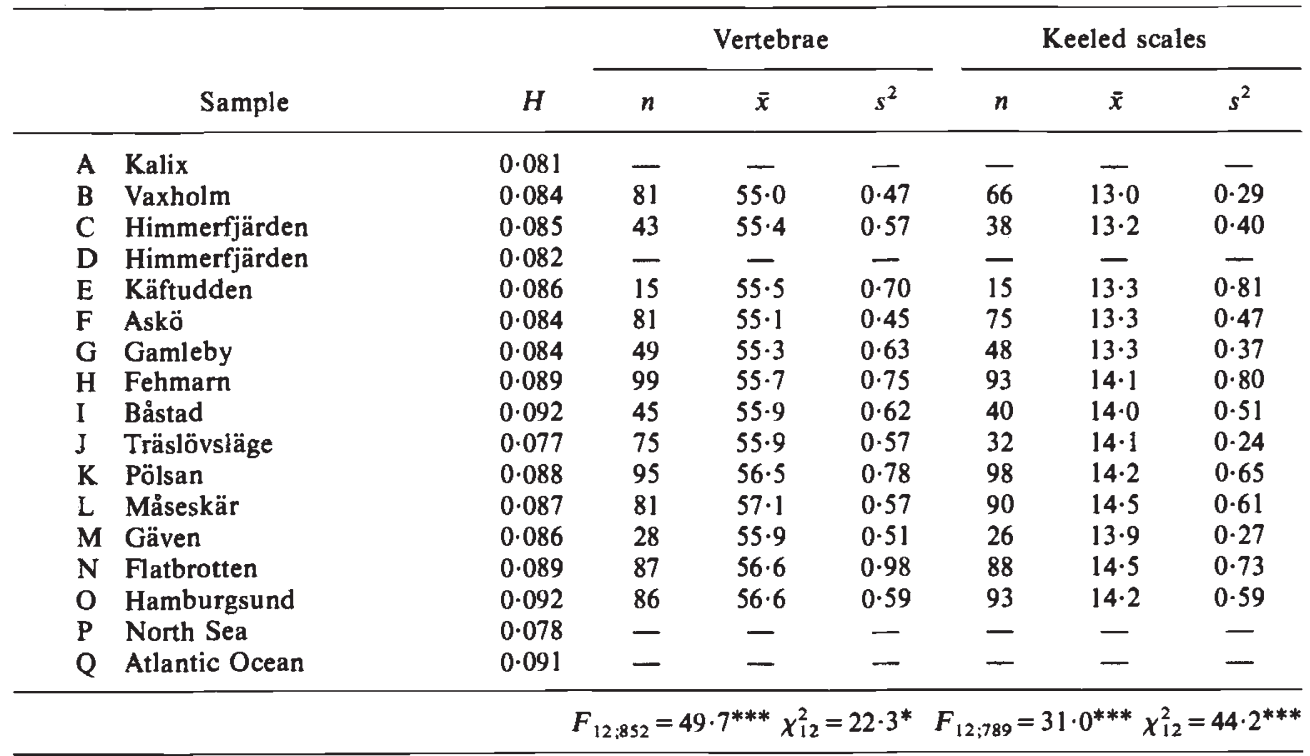

\section{MORPHOLOGIC DISTANCE (D)}

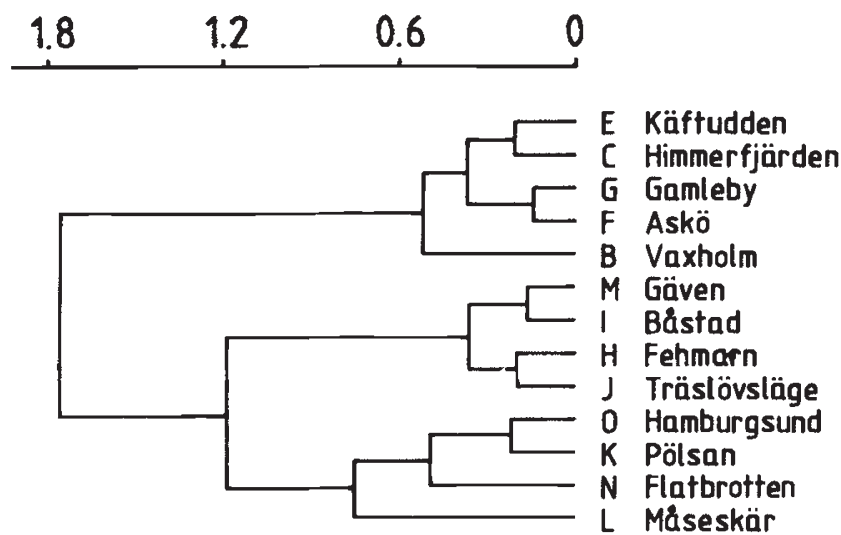

FIG. 3. Dendrogram (UPGMA; Sneath and Sokal, 1973) constructed using morphologic distances $(D)$ for the number of vertebrae $(V S)$ and keeled scales $\left(K_{2}\right) . D$ is the square root of Mahalanobis' distance (Sneath and Sokal, 1973). 
chosen to include (i) the spring spawning Baltic herring (samples $\mathrm{B}, \mathrm{C}, \mathrm{E}$, $\mathrm{F}, \mathrm{G})$, (ii) the autumn spawning Baltic herring ( $\mathrm{H}$ ), and (iii) the rest of the samples where metric measurements were available ( $I, J, K, L, M, N, O)$, all representing Kattegat or Skagerrak spring spawning herring. As estimated from nested analyses of variance (table 4 ) about 40 per cent of the variation is found among geographic groups, between 2 and 10 per cent among locations within those groups, and about 50-60 per cent within locations. The distribution of genetic variation is quite different with essentially all the variation (99.3 per cent) found within locations (table 4). The dendrogram constructed from morphologic distances (fig. 3 ) is also very different from the one constructed on the basis of genetic distances (fig. 4) for exactly the same populations, i.e., those for which metric measurements were available. The correlation between the two distance matrixes which those dendrograms are constructed from is not found to be significant $(r=-0 \cdot 18 ; \mathrm{df}=76$ with $P \gg 0.05)$.

TABLE 4

Gene diversity (16 loci, EST-4 excluded) and distribution of phenotypic variation of the number of vertebrae (VS) and keeled scales $\left(K_{2}\right)$ at different hierarchical levels. The three major geographic areas were chosen to comprise the localities $(B, C, E, F, G),(I, J, K, L, M, N, O)$, and $(H)$, respectively. The gene diversity analysis only refers to the 13 samples where metric measurements were available. $t: P<0.01, \ddagger: P<0.001$

\begin{tabular}{|c|c|c|c|c|c|c|c|c|}
\hline \multirow{3}{*}{$\begin{array}{l}\text { Hierarchical level/ } \\
\text { source of variation }\end{array}$} & \multirow{2}{*}{\multicolumn{2}{|c|}{ Gene diversity }} & \multicolumn{3}{|c|}{ Vertebrae } & \multicolumn{3}{|c|}{ Keeled scales } \\
\hline & & & \multirow[b]{2}{*}{ df } & \multirow{2}{*}{$\begin{array}{l}\text { Mean } \\
\text { square }\end{array}$} & \multirow{2}{*}{$\begin{array}{c}\text { Variance } \\
\text { component } \\
(\%)\end{array}$} & \multirow[b]{2}{*}{$\mathrm{df}$} & \multirow{2}{*}{$\begin{array}{l}\text { Mean } \\
\text { square }\end{array}$} & \multirow{2}{*}{$\begin{array}{c}\text { Variance } \\
\text { component } \\
(\%)\end{array}$} \\
\hline & Absolute & $\%$ & & & & & & \\
\hline $\begin{array}{l}\text { Between geographic areas } \\
\text { Between localities within }\end{array}$ & 0.0001 & $0 \cdot 1$ & 2 & $149 \cdot 8 \dagger$ & $41 \cdot 8$ & 2 & $87 \cdot 7 \ddagger$ & $38 \cdot 7$ \\
\hline areas & 0.0006 & 0.7 & 10 & $9 \cdot 7 \ddagger$ & $10 \cdot 7$ & 10 & $2 \cdot 0 \ddagger$ & $2 \cdot 7$ \\
\hline Within localities & 0.0863 & $99 \cdot 2$ & 852 & 0.6 & $47 \cdot 5$ & 789 & 0.6 & $58 \cdot 6$ \\
\hline Total & 0.087 & & 864 & $1 \cdot 1$ & & 801 & 0.8 & \\
\hline
\end{tabular}

Another way of testing for associations between electrophoretic and morphologic variability patterns is to compare the means and variances of morphologic characters among groups of individuals classified with respect to their heterozygosity $(0,1,2, \ldots$ etc. loci heterozygous $)$. If the heterozygosity at electrophoretic loci reflects that of loci affecting a quantitative character, then the variance of the quantitative character is expected to decrease linearly with increasing number of heterozygous loci, and depending on gene frequencies the mean will either increase or decrease (Chakraborty and Ryman, 1983). However, we found no indications of such correlations in the present material. The tests performed within locations only revealed one of the 26 correlations between heterozygosity and phenotypic value (mean) to be statistically significant. Four of the corresponding 26 correlations with variance were significant, but two of those significant correlations indicated a positive (not negative) association between variance and the number of heterozygous loci, and there was no general tendency for phenotypic variability to decrease with increasing heterozygosity. In addition to the tests performed within samples we analysed the total material 


\section{GENETIC DISTANCE}

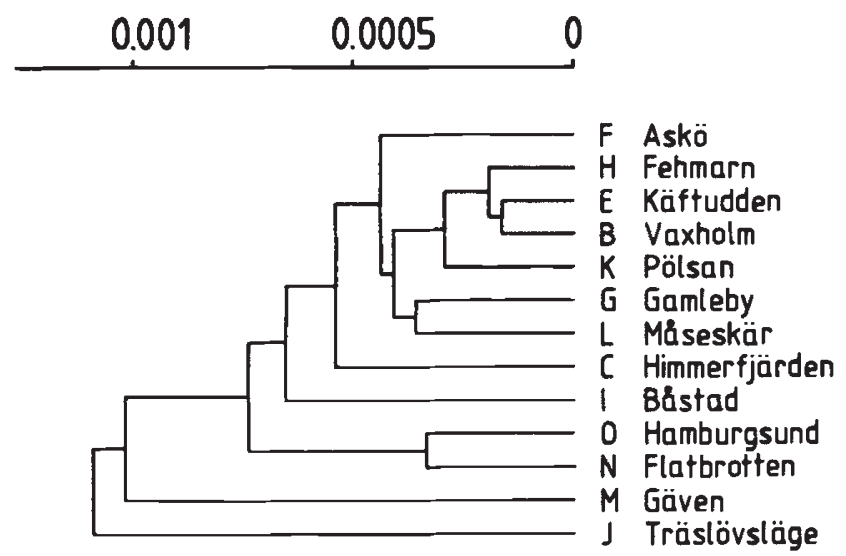

FIG. 4. Dendrogram (UPGMA; Sneath and Sokal, 1973) constructed from pairwise genetic distances (16 loci, EST-4 excluded) among the 13 samples where data on meristic characters were available.

similarly after transformation of individual phenotypic values into a common distribution with zero mean and unit variance using the conversion $z_{i j}=\left(x_{i j}-\bar{x}_{i .}\right) / s_{i,}$, where $x_{i j}$ is an individual value before transformation and $\bar{x}_{i,}$ and $s_{i}$ is the sample mean and standard deviation, respectively. It should be noted that in such a test on the total material the variances are expected to decrease with increasing heterozygosity irrespective of possible gene frequency differences among locations, whereas a trend of the means is expected only if the frequencies of the alleles affecting the quantitative character in the positive (or the negative) direction do not differ too much between locations. At any rate, there were no indications in the combined total material of heterogeneity of means or variances among groups of fish heterozygous at different numbers of electrophoretic loci $(F(4 ; 566)=1 \cdot 31$ and $F(4 ; 515)=1.09$ for homogeneity of means of the number of vertebrae and keeled scales, respectively, with $0.7>P>0.5$ in both cases; $\chi^{2}=2.83$ and $\chi^{2}=2.59$ for homogeneity of variances of the number of vertebrae and keeled scales, respectively, with $\mathrm{df}=4$ and $0.7>P>0.5$ in both cases). In summary all these findings indicate that the pattern of morphologic variation observed is only weakly, if at all, associated with genetic variability as revealed by electrophoretic loci.

\section{Discussion}

Our data indicate a remarkably small amount of genetic differentiation among ecologically and morphologically divergent groups or stocks of Atlantic herring. Although the analysis is primarily based on variable loci, which tends to inflate the estimates of intraspecific genetic differentiation, genetic distances are typically as small as 0.001 or less, and more than 99 per cent of the total gene diversity is found within locations. In the combined total material there is no consistent indication of heterozygote deficiency 
at single loci or when considering their joint genotypic distribution, or of linkage disequilibrium, as would have been expected in a genetically subdivided population. Although there are statistically significant allele frequency differences, those differences are absolutely very small and the allele and genotype frequency distributions largely resemble those expected to be observed if all samples were drawn from one single panmictic population.

There appears to be no association between the variation of the morphologic characters and that at electrophoretic loci, and that is true for the variation between as well as within locations. Of course, it is not perfectly clear how to interpret this lack of covariation between the two types of characters (McAndrew et al., 1982; Chakraborty and Ryman, 1983). At any rate, the observations are consistent with a model where the morphological characters vary independent of the part of the genome investigated by electrophoresis.

It must be stressed that the existence of only minor, or even complete absence, of electrophoretically detectable variation among different samples taken within an area does not, in itself, justify concluding that the samples of that area were drawn from a single genetically homogeneous population (Utter, 1981). Nevertheless, the finding of a very small amount of genetic differentiation is quite surprising considering the large number of ecologically and morphologically divergent stocks at different taxonomic levels that have been identified in the Atlantic herring (e.g., Parrish and Saville, 1965; Iles and Sinclair, 1982). Our study was designed to include samples of the major taxonomic groups of herring in the east Atlantic (cf. Parrish and Saville, 1965), i.e., the oceanic group, the shelf group, and the coastal herring (including the Baltic herring). It has been generally assumed that the different stocks are more or less genetically distinct, but there has been considerable disagreement about their systematic status. Our present result indicate that there is only minor (if any) genetic divergence.

These results are consistent with our previous preliminary ones (Andersson et al., 1981) and with those of Grant (1981) and Kornfield et al. (1982a). On the basis of 40 electrophoretic loci Grant (1981) estimated genetic distance between populations from different sides of the Atlantic ocean to be very close to zero, and Kornfield et al. (1982a) found no temporarily stable allele frequency heterogeneities among samples from discrete spawning grounds in the Gulf of Main and Gulf of St. Lawrence. Kornfield et al. noted that the majority of their significances were due to temporal allele frequency variations within localities (spawning grounds). In the present study we have duplicate samples from a single location only, but there is no significant heterogeneity among those samples. Nevertheless, it is possible that a lack of temporal allele frequency stability, similar to the one observed by Kornfield et al., is typical for the east Atlantic herring also. If this is true, a considerable portion of the statistically significant allele frequency differences of the present material may reflect temporal rather than spatial heterogeneity, thus supporting the concept of very little genetic differentiation among groups of herring.

Assuming that the electrophoretic loci studied are not under the influence of strong selective forces, the observation of a very small amount of genetic divergence among the units sampled is compatible with either of two alternate models. The first one implies a high rate of migration (gene flow), 
and the other one little or no migration between large populations which became isolated rather recently (e.g., within the last 100,000 years). Unfortunately, there is currently no test based on genotypic data which permits unambiguous discrimination between these two models. The loci analysed were primarily chosen on the basis of being variable in our previous study (Andersson et al., 1981) and cannot be considered an unbiased sample of electrophoretic loci. Nevertheless, there appears to be a fairly large number of alleles segregating in the stocks sampled with a total of 54 alleles at the present 17 loci, i.e., an average of 3.2 alleles per locus ( $c f$. ., Chakraborty et al., 1980). A large number of alleles is indicative of a large effective population size. However, the impression of a large effective population number may on the one hand be realized by effectively large subpopulations which became recently isolated, or by a large species effective size maintained by gene flow between subpopulations (Nei, 1975, p. 222). In this situation non-genetic data must be sought to support either hypothesis. The observation by Anokhina (1971) that spring spawners may turn into autumn spawners and vice versa indicates that at least some gene flow occurs, even between stocks which are usually considered to be taxonomically very different (e.g., Parrish and Saville, 1965). If gene flow is not insignificant, ecologic and morphologic stock differences are either environmentally induced or reflecting genetic differentiation at loci which are most likely under the influence of selection (Endler, 1977). The observation that several characters used for stock discrimination can be environmentally modified (e.g., Blaxter, 1958), suggests that morphologic divergence between stocks may to a large extent be the result of environmental heterogeneity.

It has been suggested by several authors (e.g., Blaxter, 1958; Svärdson, 1966) that spring and autumn spawners of the east Atlantic should be given the systematic status of distinct species. There is no support for this conjecture in our present data. On the other hand, Kornfield et al. (1982a) found evidence of consistent allele frequency heterogeneities between autumn and spring spawners of the west Atlantic. However, the amount of divergence was very small and genetic identities calculated on the basis of 13 electrophoretic loci were all larger than 0.99 , i.e., values typical for local populations of the same species (Nei, 1975). Moreover, recalculation of the data published by Kornfield et al. (1982a) revealed that almost all (98.6 per cent) of the total gene diversity is due to variation within samples, and only 0.2 per cent is explained by differences between fall and spring spawning stocks. Anokhina (1971) also found that herring may shift the time for spawning and that such shifts were induced by environmental changes. Altogether, these observations indicate that spring and autumn spawning stocks should not be given species rank; it might be more appropriate to consider them as local populations with a substantial amount of gene flow and a high degree of genetic similarity between them. It is thus possible that the herring is a species showing ecological or trophic polymorphisms comparable to those described for Ilyodon (Turner and Grosse, 1980) and cichlids (Kornfield et al., 1982b).

Do electrophoretic loci give a correct picture of the amount of genetic divergence among herring stocks? Of course, this question cannot be answered without direct examination of the pattern of differentiation at other parts of the genome, e.g., through examination of enzymatically fragmented mitochondrial or nuclear DNA. It should be noted, however, 
that there are no indications of a general slow-down of the rate of protein evolution in Clupea. This is supported by the observation by Grant (1981), who estimated evolutionary time on the basis of genetic distance ( 40 loci) between races of Pacific herring (Clupea pallasi) as well as between Pacific herring and Atlantic herring; he found that the electrophoretically estimated time since divergence was consistent with the time of the geological events assumed to have separated the current groups. It should also be noted that there are no indications that the low levels of genetic divergence observed in the present study should be explained by technical problems or inability to detect existing electrophoretic variability. We have found allozymic variation at more than half of the loci examined ( $c f$. , Andersson et al., 1981) and the high genetic similarity is not due to apparent fixation of identical alleles at seemingly monomorphic loci, but to similar allele frequencies at variable ones.

The pattern for distribution of genetic variation at electrophoretic loci has frequently been suggested to correlate with various environmental factors such as temperature, salinity, environmental heterogeneity, etc. (e.g., Nevo, 1978; Koehn et al., 1980; Gartner-Kepkay et al., 1983). The present study is relevant to this question as there is pronounced environmental heterogeneity among the locations sampled. The most obvious difference refers to the gradient in salinity ranging from 3.2 per cent in the Atlantic Ocean and steadily decreasing down to $0 \cdot 1-0 \cdot 2$ per cent in the upper Gulf of Bothnia. The number of marine organisms in the animal community decreases with decreasing salinity, and the herring is one of the few marine organisms that can reproduce in the upper Gulf of Bothnia. However, as determined by electrophoresis this environmental heterogeneity is not reflected in the genetic profiles of the populations sampled.

Iles and Sinclair (1982) recently suggested that the number of genetically distinct herring stocks is determined by a number of distinct, geographically stable larvae retention areas. They presented data strongly suggesting that tidally or other geographically stable retention mechanisms are associated with the spawning area of each particular stock. However, in the light of the present findings it seems more likely that different environmental conditions among retention areas constitute the basis for the morphological and ecological divergence between spawning groups. As pointed out by Ihssen et al. (1981), observed electrophoretic differences is a sufficient but not necessary condition for groups of fish to be genetically differentiated. However, current data indicate that stocks either diverged rather recently or that the amount of gene flow between groups of fish classified as stocks has been large enough to prevent substantial differentiation. From the perspective of fisheries management it is still possible that stocks should be treated as management units, but there is a strong need for a careful examination of alternate management strategies assuming that many of the current stocks are genetically very similar.

Acknowledgments. We are indebted to G. Aneer, O. Leimar, G. Ståhl and F. Utter for helpful comments on the manuscripts, and to R. Bailey, K. Jørstad and F. Thurow for providing samples for the electrophoretic analysis. The study was supported by grants from the Swedish Natural Science Research Council, and in part by the National Institutes of Health (GM 28574). 


\section{REFERENCES}

ACKEFORS, H. 1977a. The meristic characters and the maturity cycle of the Skagerrak spring spawners. Medd. Havsfiskelab., Lysekil, 227, 12 p.

ACKEFORS, H. $1977 b$. The life-cycle of Kattegat spring spawners in relation to growth rate, the development of gonads and the fat content. Medd. Havsfiskelab., Lysekil, 228, 7 p.

ANDERSSON, L., RYMAN, N., ROSENBERG, R. AND STÃHL, G. 1981. Genetic variability in Atlantic herring (Clupea harengus harengus): description of protein loci and population data. Hereditas, 95, 69-78.

ANEER, G. 1979. On the ecology of the Baltic herring with special reference to the AsköLandsort area. Ph.D. thesis Univ. Stockholm, Sweden.

ANOKHINA, L. 1971. Maturation of Baltic and White Sea herring with special reference to variations in fecundity and egg diameter. Rapp. Cons. Explor. Mer, 160, 12-17.

BLAXTER, J. H. S. 1958. The racial problem in Herring from the viewpoint of recent physiological, evolutionary, and genetical theory. Rapp. Cons. Explor. Mer, 143, 10-19.

BÜCKMAN, A. AND PARRISH, B. B. 1958. Conclusions reached at special scientific meeting on "Herring races" held at Charlottenlund on 25-27 September 1956. Rapp. Cons. Explor. Mer, 143, 8-9.

CHAKRABORTY, R. 1980. Gene diversity analysis in nested subdivided populations. Genetics, 96, 721-726.

CHAKRABORTY, R. 1981. The distribution of the number of heterozygous loci in an individual in natural populations. Genetics, 98, 461-466.

CHAKRABORTY, R., FUERST, P. A. AND NEI, M. 1980. Statistical studies on protein polymorphism in natural populations. III. Distribution of allele frequencies and the number of alleles per locus. Genetics, 94, 1039-1063.

CHAKRABORTY, R., HAAG, M., RYMAN, N. AND STAHL, G. 1982. Hierarchical gene diversity analysis and its application to brown trout population data. Hereditas, 97, 17-21.

CHAKRABORTY, R. AND RYMAN, N. 1983. Relationship of mean and variance of genotypic values with heterozygosity per individual in a natural population. Genetics, 103, 149-152.

EMIGH, T. H. 1980. A comparison of tests for Hardy-Weinberg equilibrium. Biometrics, 36, 627-642.

ENDLER, J. A. 1977. Geographic variation, speciation, and clines. Princeton Univ. Press, Princeton, New Jersey.

FELSENSTEIN, J. 1982. Numerical methods for inferring evolutionary trees. The Quarterly Review of Biology, 57, 379-404.

GARTNER-KEPKAY, K. E., ZOUROS, E., DICKIE, L. M. AND FREEMAN, K. R. 1983. Genetic differentiation in the face of gene flow: a study of mussel populations from a single Nova Scotian embayment. Can. J. Fish. Aquat. Sci, 40, 443-451.

GRANT, W. S. 1981. Biochemical genetic variation, population structures, and evolution of Atlantic and Pacific herring. Ph.D. thesis Univ. Washington, Seattle, USA.

HEINCKE, F. 1898. Naturgeschichte des Herings. Teil I. Die Lokalformen und die Wanderungen des Herings in den Europäischen Meeren. Abh. dtsch. Seefisch Ver., 2.

HEMPEL, G. AND BLAXTER, J. H. 1961. The experimental modification of meristic characters in herring (Clupea harengus L.). Rapp. Cons. Explor. Mer, 26, 336-346.

HILL, W. G. 1974. Estimation of linkage disequilibrium in randomly mating populations. Heredity, 33, 229-239.

IHSSEN, P. E., BOOKE, H. E., CASSELMAN, J. M., MCGLADE, J. M., PAYNE, N. R. AND UTTER, F. M. 1981. Stock identification: materials and methods. Can. J. Fish. Aquat. Sci., 38, $1838-1855$.

ILES, T. D. AND SINCLAIR, M. 1982. Atlantic herring: stock discreteness and abundance. Science, 215, 627-633.

KOEHN, R. K., NEWELL, R. I. E. AND IMMERMAN, F. 1980. Maintenance of an aminopeptidase allele frequency cline by natural selection. Proc. Natl. Acad. Sci., 77, 5385-5389.

KORNFIELD, I., GAGNON, P. S. AND SIDELL, B. D. 1981. Inheritance of allozymes in Atlantic herring (Clupea harengus harengus). Can. J. Genet. Cytol., 23, 715-720.

KORNFIELD, I., SIDELL, B. D. AND GAGNON, P. S. $1982 a$. Stock definition in Atlantic herring (Clupea harengus harengus): genetic evidence for discrete fall and spring spawning populations. Can. J. Fish. Aquat. Sci., 39, 1610-1621.

KORNFIELD, I., SMITH, D. C., GAGNON, P. S. AND TAYLOR, J. N. 1982b. The cichlid fish of Cuatro Ciénegas, Mexico: direct evidence of conspecificity among distinct trophic morphs. Evolution, 36, 658-664. 
MCANDREW, B. J., WARD, R. D. AND BEARDMORE, J. A. 1982. Lack of relationship between morphological variance and enzyme heterozygosity in the plaice, Pleuronectes platessa. Heredity, 48, 117-125.

NEI, M. 1973. Analysis of gene diversity in subdivided populations. Proc. Natl. Acad. Sci., 70, 3321-3323.

NEI, M. 1975. Molecular population genetics and evolution. North-Holland, Amsterdam.

NEI, M. 1978. Estimation of average heterozygosity and genetic distance from a small number of individuals. Genetics, $89,583-590$.

NEI, M. AND LI, W.-H. 1973. Linkage disequilibrium in subdivided populations. Genetics, 75, 213-219.

NEvo, E. 1978. Genetic variation in natural populations: patterns and theory. Theor. Popul. Biol., 13, 121-177.

PARRISH, B. B. AND SAVILlE, A. 1965. The biology of the north-east Atlantic herring populations. Oceanogr. Mar. Biol. Ann. Rev., 3, 323-373.

PETURSSON, P. M. AND ROSENBERG, R, 1982. Maturity and growth of the spring spawning herring in the Kattegat-Skagerrak. Ophelia, 21, 195-204.

ROSENBERG, R. AND PALMÉN, L. E. 1982. Composition of herring stocks in the SkagerrakKattegat and the relations of these stocks with those of the North Sea and adjacent waters. Fish. Res., 1, 83-104.

SLATKIN, M. 1981. Estimating levels of gene flow in natural populations. Genetics, 99, 323-335. SNEATH, P. H. AND SOKAL, R, R, 1973. Numerical taxonomy. W. H. Freeman and Co., San Francisco.

SOKAL, R. R. AND ROHLF, F. J. 1981. Biometry, 2nd ed. W. H. Freeman and Co., San Francisco. SVÄRDSON, G. 1966. Young sibling fish species in northwestern Europe, p. 498-513. In W. F. Blair (ed.), Vertebrate speciation. Univ. Texas Press, Austin.

TURNER, B. J. AND GROSSE, D. J. 1980. Trophic differentiation in Ilyodon, a genus of streamdwelling goodeid fishes: speciation versus ecological polymorphism. Evolution, 34, 259270.

UTTER, F. M. 1981. Biological criteria for definition of species and distinct intraspecific populations of anadromous salmonids under the U.S. Endangered Species Act of 1973. Can. J. Fish. Aquat. Sci., 38, 1626-1635.

VITHAYASAI, C. 1973. Exact critical values of the Hardy-Weinberg test statistic for two alleles. Commun. in Stat., 1, 229-242. 